\title{
IMPROVING STUDENTS' VOCABULARY USING POSTER MEDIA FOR SECOND GRADE HEARING DISABLE AT SMALB
}

\author{
Iis Siti Sa'adah', Ani Atikah² \\ ${ }^{1}$ IKIP Siliwangi \\ ${ }^{2}$ IKIP Siliwangi \\ iis.saadah92@gmail.com, ${ }^{2}$ alvin.faiz602@gmail.com
}

\begin{abstract}
The objective of the study is to improve vocabulary in children with special need. The researchers have chosen the object in the school because, the school has lack of learning media and teachers. This research used the "Poster" as a media, in addition the poster can make the students more interest to learn. The researchers using Poster media with a carton paper converted into a tree viewer and students are required to fill in a blank section of the tree shape based on a pre- existing question on the poster containing the Vocabulary subject Noun and Verb. Vocabulary with visuals so that they are easier to learn which tend to be limited by the ability they (deaf students) have. The researchers used Class room Action Research (CAR).The steps in action research (planning, action, observation, and reflection) are done in a cycle. This method is one of the active learning strategy by involving students to always study English learning especially The results of this research showed that the poster media can improve the vocabulary of the students and the students more interested to learn vocabulary.
\end{abstract}

Keywords: Vocabulary Understanding, Deaf, poster Media

\section{INTRODUCTION}

According to Parmawati (2016), English is used in many activities either orally or in written form. There are many fields which can be seen dealing with the role of English, such as: technology, health, tourism, correspondence, etc. However, since English in Indonesia is a foreign language, most students at any level of education get difficulty in reading English text. Many research results (Hamra, 1993 and 1996; Mardiana, 1993; Kweldju 2001 cited in Apsari, 2010) indicated that the ability of Indonesian students to read English texts was very low. One of the language element in reading is vocabulary.

Learning language cannot separate from learning vocabulary. Vocabulary is vital to communicating with others and understanding what one is reading. Vocabulary supports the speaker to express their opinions, ideas, and feelings in communication. Vocabulary is the most important component language because it affects the four language skill, there are listening, speaking, reading, and writing. Hiebert \& Kamil (2005) stated that generically, vocabulary is the knowledge of meanings of the words. From definition above means that vocabulary is need by every person, by having a language vocabulary people can express their ideas and ask for inform `ation and without production word any land of knowledge is useless. 
According to Parmawati and Yugafiati (2017), one of the purposes of teaching English as a foreign language to Indonesian people is that they can read, grasp the idea, and understand the book written in English. According to Nunan (2003), "reading is a fluent process of readers combining information from a text and their own background knowledge to building meaning". Reading can not be separated from daily activities. People read many kinds written materials According to Parmawati (2016), English is used in many activities either orally or in written form. There are many fields which can be seen dealing with the role of English, such as: technology, health, tourism, correspondence, etc. However, since English in Indonesia is a foreign language, most students at any level of education get difficulty in reading English text. Many research results (Hamra, 1993 and 1996; Mardiana, 1993; Kweldju 2001 cited in Apsari, 2010) indicated that the ability of Indonesian students to read English texts was very low. One of the language element in reading is vocabulary.

Learning language cannot separate from learning vocabulary. Vocabulary is vital to communicating with others and understanding what one is reading. Vocabulary supports the speaker to express their opinions, ideas, and feelings in communication. Vocabulary is the most important component language because it affects the four language skill, there are listening, speaking, reading, and writing. Hiebert \& Kamil (2005) stated that generically, vocabulary is the knowledge of meanings of the words. From definition above means that vocabulary is need by every person, by having a language vocabulary people can express their ideas and ask for information and without production word any land of knowledge is useless.

According to Thalib (2010), with special needs defined as individuals who have different characteristics than other invidu which is in normal view by society in general. more specifically, children with special needs exhibit lower or higher physical, intellectual, and emotional characteristics than normal children of their own age, or beyond the norms of norms prevailing in society whether they are 'up' or 'down' both in terms of physical, intellectual and emotional so as to have difficulty in achieving success both in terms of personal social and educational activities

By studying vocabulary student should be able to communicate using the English language tocommunicate even with the limitations in they experience. because in the modern era as now social equality becomes a natural things in social societies, especially in the language then therefore using "poster" is expected to facilitate students in understanding the word per word in a vocabulary learning as fun method.With the development of technology and the globalization era so rapidly that in communicating it is not only include Indonesian language but must understand about other foreign languages as well as English. therefore the author is interested to discuss vocabulary because it becomes a supporting factor in language communication, especially in English. but in this case the authors intend to help students with special needs in language, especially for deaf children with poster learning method because they are limited with hearing and difficult to speak or argue thoroughly in understanding vocabulary itself and how important it is a factor in language support. 
For increasing the students in English vocabullary, the researchers picture media in the process of learning in the classroom. Media is helping to increasing the students interest in learning process, so that the receivers can learn effectively and efficiently. There are three kinds of media that can be used in learning teaching process. 1) Visual, for example: pictures and photos. 2) Audio, for example: tape recorder, cassettes, and radio. 3) Audiovisual, for example: movies, and videos.

In general, posters can be defined as announcements or advertisements in the form of drawings or posts embedded in a wall or place of common that are strategic for easy viewing.

\section{METHOD}

In this research, the writer used Classroom Action research. According to Wiriaatmaja, Rochiati (2005, as cited in Parmawati, 2017), This research composed for two or more cycles then itobserved and evaluated to identify all facts including the success and the failure of the action. It means that the action should be stopped or continued and revised to the next cycle based on the selected criteria of success. This belongs to qualitative research. Qualitative research is exciting and important. It is a highly rewarding activity because it engages us with things that matter, in ways that matter. Through qualitative research we can explore a wide array of dimensions of the social world, including the texture and weave of everyday life, the understandings, experiences and imaginings of our research participants, the ways that social processes, institutions, discourses or relationships work, and the significance of the meanings that they generate (Mason, 2002).

In gathering the data, this study employed various techniques such as classroom observation, questionnaire and interview. The first is the data obtained directly from the students that the students say again the vocabulary spoken by the researchers. Second, data is also obtained through questionnaires (learning style and motivation). Third is the interview to the students. Fourth is the result of observation of the application of poster media Learning in class.

During the observation, the writer used field note as the main instrument.It is used in order to observe what is going on or what is happening in the observed context (Fraenkel and Wallen, 2008, as cited Apsari and yana, 2015).

In addition, in this study, the interview was used to gain specific information or very useful data about students' feeling or opinion which is notaccessible through observation (Merriam, 1998, cited in Apsari, 2018). Furthermore, the data analysis was conducted during and after the research took place.

In addition, Creswell (2012, as cited in Aryana and Apsari, 2018) states that "Analyzing qualitative data requires understanding how to make sense of text and image, so that you can form answers to your research questions".

In this study, the data was analyzed by using the constant comparative method as suggested by Strauss and Glasser in Lincoln and Guba (1985, as cited in Mundriyah and Parmawati, 2016). 
The process includes the following steps:

1. Observe the students during teaching and learning process. The observation sheet contains some indicators that show the students' activities.

2. Analyze the result of the interview to find out the information about the implementation of poster Media in teaching Vocabulary

3. Analyze the result of the questionnaire to know the students personal impression about the use of poster Media in teaching Vocabulary

\section{RESULTS AND DISCUSSION}

\section{Results}

In this situation that we knew about the technology and the globalization era so rapidly that in communicating it is not only include Indonesian language but must understand about other foreign languages as well as English. therefore the author is interested to discuss vocabulary because it becomes a supporting factor in language communication, especially in English. but in this case the authors intend to help students with special needs in language, especially for deaf children with poster learning method because they are limited with hearing and difficult to speak or argue thoroughly in understanding vocabulary itself and how important it is a factor in language support

\begin{tabular}{|c|c|c|c|c|}
\hline No & Name & Motivation & interest & Active \\
\hline 1 & Student 1 & $\begin{array}{l}\text { having a vocabulary } \\
\text { understanding that is } \\
\text { quite prominent among } \\
\text { the others }\end{array}$ & $\begin{array}{l}\text { from the test results } \\
\text { given, } \\
\text { significantly increased } \\
\text { understanding of vocab }\end{array}$ & $\begin{array}{l}\text { quite active in the } \\
\text { class, } \\
\text { nt, confide } \\
\text { responding quickly } \\
\text { responsiveness to the } \\
\text { material presented. }\end{array}$ \\
\hline 2 & Student 2 & 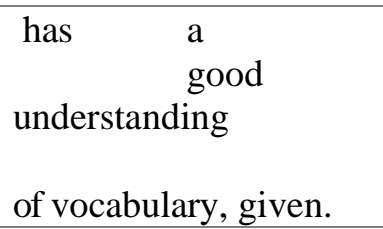 & $\begin{array}{l}\text { have an increase in } \\
\text { understanding from the } \\
\text { test results vocab }\end{array}$ & $\begin{array}{l}\text { lack of confidence in } \\
\text { conveying something }\end{array}$ \\
\hline 3 & Student 3 & $\begin{array}{l}\text { The understanding of } \\
\text { vocab given sometimes } \\
\text { forgot again, so } \\
\text { reminded, } \\
\text { remember again. }\end{array}$ & $\begin{array}{l}\text { can immediate } \\
\text { ly understand the } \\
\text { material presented }\end{array}$ & $\begin{array}{l}\text { given the test, and } \\
\text { given a little } \\
\text { explanation, quickly } \\
\text { responsive }\end{array}$ \\
\hline 4 & Student 4 & $\begin{array}{l}\text { just forget it often, and } \\
\text { must often be } \\
\text { reminded or repeated }\end{array}$ & $\begin{array}{l}\text { the test results given } \\
\text { have an increase about } \\
\text { vocabulary } \\
\text { understanding. }\end{array}$ & active in learning, \\
\hline
\end{tabular}




\begin{tabular}{|c|c|c|c|c|}
\hline No & Name & Motivation & interest & Active \\
\hline 5 & Student 5 & $\begin{array}{l}\text { must also be reminded } \\
\text { again often, easy to } \\
\text { forget, a day } \\
\text { understand, } \\
\text { tomorrow asked to } \\
\text { forget again, reminded, } \\
\text { just remember }\end{array}$ & $\begin{array}{l}\text { from the test results } \\
\text { there is an increase in } \\
\text { change. }\end{array}$ & $\begin{array}{l}\text { good enough } \\
\text { in } \\
\text { classroom learning }\end{array}$ \\
\hline
\end{tabular}

\section{Discussion}

The research carried on the second grade at SMALB AL-Hikmah Padalarang for 6 meetings. for 6 meetings. The six meetings were categorized into 2 cycles. The result of each cycle will be organized on four steps of CAR, namely : (1) planning, (2) acting, (3) observing, and (4) reflecting.

Cycle 1 On planning section, the researchers prepared some lesson plans to teach vocabularies and put them into a poster. Lesson plans were made to be implemented on treatment1, and 2, which contained some proceduresin classification of some word into the poster.In this cycle, the researchers found some problems of learning process and prepared for next meeting to be better strategies. Six meeting, the researchers provided some word to arranged by students. The steps of acting and observing are displayed on table 1 below :

Table 1. Meetings in Cycle 1

\begin{tabular}{cll}
\hline \multicolumn{1}{c}{ Acting } & \multicolumn{1}{c}{ Observing } \\
\hline Meeting & \multicolumn{1}{c}{ Topic } & \multicolumn{1}{c}{ Activity } \\
\hline $\mathbf{1}$ & $\begin{array}{l}\text { Practice 1 : } \\
\text { stick word on poster }\end{array}$ & $\begin{array}{l}\text { In this first meeting, the researchers give } \\
\text { them a } \\
\text { pre-test which consist of the meaning of } \\
\text { words (subject), noun, and verb. }\end{array}$ \\
\hline $\mathbf{2}$ & $\begin{array}{l}\text { Treatment 1 : } \\
\text { Classification the words on } \\
\text { the poster. }\end{array}$ & $\begin{array}{l}\text { The students try to understand about the } \\
\text { material one by one. Students learn the } \\
\text { material with some visual media and make } \\
\text { them easy to remember the material, the } \\
\text { students come in front to the class for } \\
\text { classifing the word one by } \\
\text { one. }\end{array}$ \\
& $\begin{array}{l}\text { Treatment } 2: \\
\text { Arrange the word to be a } \\
\text { good sentence. }\end{array}$ & $\begin{array}{l}\text { Inis meeting, the teacher give some word } \\
\text { about subject, noun, and verb. every students } \\
\text { work individualy to arrange the word to be a } \\
\text { good sentences .and understanding the } \\
\text { meaning of that senteces. Students try to } \\
\text { write the sentences in front of class } \\
\text { atwhiteboard. } \\
\text { Students do this activity using poster. }\end{array}$ \\
&
\end{tabular}


$4 \quad$ Practice 2:

In this meeting, the researchers conducted Write 5 sentences using words on the poster. post- test which consists 5 number of test and intruction them to write 5 sentences using words that has been provide. The questions presented in the same form and level of difficulty with the pre-test.

Therefore, the cycle II was carried out to continue the research.

Cycle II. This cycle only covered four steps as stated in cycle I. In planning session, theresearchers made some revision towards lesson plans. On the previous treatment, some students be an active. The acting session covered three meetings, since the practice 1 used for this cycle was taken from the practice 2 from the previous cycle as seen on table 2 below :

Table 2 Meetings in cycle II

\begin{tabular}{cll}
\hline Meeting & \multicolumn{1}{c}{ Acting } & \multicolumn{1}{c}{ Topic } \\
\hline $\mathbf{5}$ & $\begin{array}{l}\text { Treatment 3: } \\
\text { Understanding } \\
\text { poster. }\end{array}$ & $\begin{array}{l}\text { Observing } \\
\text { Activity }\end{array}$ \\
\hline $\mathbf{6}$ & $\begin{array}{l}\text { The researchers continued the material to make } \\
\text { students more understanding. Repeat and repeat } \\
\text { anderstanding the sentences } \\
\text { from word at the poster. }\end{array}$ & $\begin{array}{l}\text { On this treatment, students analize the sentences } \\
\text { student words about subject verb and noun one } \\
\text { by one, for make sure that they understand. }\end{array}$ \\
& $\begin{array}{l}\text { which a subject, verb and noun. Students } \\
\text { search what the meaning of the sentences and } \\
\text { understand it. }\end{array}$
\end{tabular}

\section{CONCLUSION}

Based on the data analysis and the result of discussion of findings, it can be concluded that the poster media can improve students' especially in learning english vocabulary to deaf students' at SMALB AL-HIKMAHFrom the result of this study some sugesstion to note include:

1. using poster media in teaching english vocabulary is recommended for english teachers, especially for deaf students, teachers to attract the students interest in learning english. And By using series picture as media. The students are suggested to be better to learning in English vocabulary.

2. the teachers has to use some variants of media in teaching english so the students felt the interest in learning. To arising and increasing students English learning, the teacher must be creative, do not rely on textbook, and uses the media.

3. for the other researchers to conduct other research on the same field using the other form of poster media applied in other skills, such as: listening, speaking, reading and writing 


\section{ACKNOWLEDGMENTS}

This article is the result of hard work,support and guidance of several people. I would like to express our biggest gratitude to our supervisior, parents, institution and friends as for their valuable advaice, motivation and important feedback

\section{REFERENCES}

Apsari, Y., \& Yana, Y. (2015). Teachers'techniques And Problems In

Teaching Reading. P2M STKIP Siliwangi, 2(2), 217-233.

Apsari, Y. (2018). Reflective Reading Journal In Teaching Writing. Indonesian EFL Journal, 4(2), 39-47.

Aryana, S., \& Apsari, Y. (2018). Analysing Teacher's Difficulties In Teaching Listening. Eltin Journal, Journal of English Language Teaching in Indonesia, 6(2), 100-106.

Gray, D. E. (1995). Hearing-impaired children, initial literacy and computer assisted learning. $P Q D T$ - $U K$ \& Ireland, (November), 248. Retrieved from https://queens.ezp1.qub.ac.uk/login?url=https://search.proquest.com/docview/3015363 61

?accountid=13374\%0Ahttp://resolver.ebscohost.com/openurl?ctx_ver=Z39. 88- 2004\&ctx_enc=info:ofi/enc:UTF8\&rfr_id=info:sid/ProQuest+Dissertations+\%26+Theses\%3A+UK+\%26+Ir elan

Hiebert, E. H., \& Kamil, M. L. (2005). Teaching and Learning Vocabulary. New York: Routledge. https://doi.org/10.4324/9781410612922

Mason, J. (2002). Qualitative Researching - Jennifer Mason - Google Buku (second). Los Angels : sage publication ltd.

Mundriyah, M., \& Parmawati, A. (2016). USING THINK-PAIR-SHARE (TPS) TO IMPROVE STUDENTS'WRITING CREATIVITY (A Classroom Action Research in the Second Semester Students of STKIP Siliwangi Bandung). P2M STKIP Siliwangi, 3(2), 84-91.

Padden, Carol; Ramsey, C. (1997). Deaf Students as Readers and Writers: A Mixed-Mode Research. Educational Resources Information Center (ERIC). Retrieved from https://files.eric.ed.gov/fulltext/ED413688.pdf

Parmawati, A., \& Yugafiati, R. (2017). USING AUTHENTIC MATERIAL TO IMPROVE STUDENTS'READING INTEREST (A Classroom Action Research in the Second Semester Students of STKIP Siliwangi Bandung). ELTIN JOURNAL, Journal of English Language Teaching in Indonesia, 5(1), 1-8.

Richards, J., \& Schmidt, R. (2002). Longman Dictionary of Language Teaching. New York: Routledge. 
Thalib S.B. (2010). Psikologi Pendidikan Berbasis Analisis Empiris Aplikatif - Prof. Dr. Syamsul Bachri Thalib, M.Si. - Google Buku (1st ed.). JAKARTA: Kencana Media Group. 